\title{
CHANGES IN WOOD ANATOMY IN TREE RINGS OF PINUS PINASTER AIT. FOLLOWING WOUNDING BY FLASH FLOODS
}

\author{
J. A. BALlESTEROS ${ }^{1 *}$, M. STOFFEL ${ }^{2,3,4}$, J. M. BODOQUE ${ }^{5}$, M. BOLLSCHWEILER ${ }^{2,3,4}$, O. HITZ ${ }^{4}$, and \\ A. DÍEZ-HERRERO ${ }^{1}$ \\ ${ }^{1}$ Department of Research and Geoscientific Prospective, Geological Survey of Spain (IGME), Ríos Rosas 23, \\ Madrid E-28003, Spain \\ ${ }^{2}$ Laboratory of Dendrogeomorphology, Institute of Geological Sciences, University of Berne, CH-3012, Berne, Switzerland \\ ${ }^{3}$ Climatic Change and Climate Impacts, Institute for Environmental Sciences, University of Geneva, CH-1227 Carouge- \\ Geneva \\ ${ }^{4}$ Department of Geosciences, Geography, chemin du Musée 4, University of Fribourg, CH-1700 Fribourg, Switzerland \\ ${ }^{5}$ Mining and Geological Engineering Department, University of Castilla La Mancha, Campus Fábrica de Armas, Avda. \\ Carlos III, Toledo E-45071, Spain
}

\begin{abstract}
This paper analyzes the anatomical response of Pinus pinaster Ait. following wounding by flash floods. A total of 14 wood samples were taken from 14 different scarred trees located on the river banks of the Arroyo Cabrera torrent (Spanish Central System). In addition, 20 increment cores were collected from undisturbed and healthy $P$. pinaster trees to build a local reference chronology. For the injured trees, analysis focused on growth changes in early earlywood (EE) tracheids, namely on differences in (i) lumen size; (ii) cell-wall percentage and cell-wall thickness; (iii) radial length and tangential width of tracheids; as well as (iv) in the abundance of resin ducts in earlywood (EW) and latewood (LW) following wounding. Results indicate that tissues bordering flash-flood wounds are characterized by reduced growth rates and a decrease of EE tracheid lumen area by $51 \%$. In addition, cell-wall percentage increases by $34 \%$ in the increment rings formed after the event and significant changes are observed in the radial length and tangential width of EE tracheids. Observations on resin ducts do not yield any significant results. Based on these anatomical parameters, detecting and dating past flash-flood events in growth rings is now possible for Mediterranean species, specifically $P$. pinaster.
\end{abstract}

Keywords: tree rings, dendrogeomorphology, wood anatomy, lumen, tracheids, resin ducts, flash floods, Maritime pine, Pinus pinaster Ait.

\section{INTRODUCTION}

Floods and the associated overflowing of fluvial or torrential channels as well as the water accumulation in endoreic areas represent a hazard with great associated socio-economic losses worldwide (Scheuren et al. 2009). In Mediterranean areas, flash floods are especially common (Roca et al. 2009) and characterized by both extremely high discharge and important debris transport rates as well as by an abrupt rise and fall of flood hydrographs combined with high flow velocities. As a result, they can pose hazards to society because of their sudden occurrence and the lack of

* Corresponding author: ja.ballesteros@gme.es risk perception. In mountain areas, where precipitation and flow gauges are infrequently present, dendrogeomorphological methods (Alestalo 1971) represent one of the most accurate indirect data sources for the dating of events that have occurred several decades or centuries ago (e.g. Bollschweiler et al. 2008a; Stoffel et al. 2008). Growth disturbances in tree-ring series allow for an assessment of the magnitude and frequency of past flash-flood events and thus for the realization of hazard maps (Stoffel and Bollschweiler 2008).

Since the late 1960s, dendrogeomorphological studies have focused on the reconstruction of floods through the dating of scars caused by impacts of boulders, ice or woody debris transported by water (e.g. Harrison and Reid 1967; McCord 1996; 
Gottesfeld 1996; Tardif and Bergeron 1997; Zielonka et al. 2008; Bollschweiler et al. 2008a). In addition, anatomical 'flood signatures' resulting from prolonged flooding in large rivers have been assessed in different broadleaved species (e.g. Yanosky 1984; Hupp 1988; Astrade and Bégin 1997; St George et al. 2002). However, in spite of this previous experience, dendrogeomorphological methods have not been used so far to assess flashflood processes in Mediterranean basins. This is a result of circumstances that are related to the specific characteristics of Mediterranean ecosystems as well as to the tree species existing in these environments. On one hand, the analysis of scars usually requires the use of destructive sampling strategies based on the collection of cross-sections or large wedges from stems. Normally, such sampling strategies require the sacrifice of trees (Yanosky and Jarret 2002), which makes these methods undesirable, especially in fragile and vulnerable riparian ecosystems. On the other hand, the wood-anatomical response of Mediterranean conifers to fluvial processes has never been analyzed before. This lack of characterization of anatomical signatures (sensu Schweingruber 2001; Wimmer 2004) associated with flash floods of Mediterranean tree species has prevented the use of non-destructive sampling with increment cores so far, inhibiting the development of dendrogeomorphological techniques in applied flood-hazard analysis.

In this paper, Maritime pine (Pinus pinaster Ait.) trees have been analyzed to identify anatomical changes in the wood structure induced by flash-flood processes to this abundant Mediterranean conifer species so as to allow future research of the spatio-temporal activity of flash floods using non-destructive sampling methods. We report on preliminary results obtained from 14 microslides prepared from stem wedges taken from flash-flood wounds in fourteen different trees. Analysis focused on changes in the structure of early earlywood (EE) tracheids as well as on changes in the number and occurrence of resin ducts in earlywood (EW) and latewood (LW).

\section{STUDY AREA}

This study was conducted along the banks of the Arroyo Cabrera torrent $\left(40^{\circ} 24^{\prime} 28^{\prime \prime} \mathrm{N}\right.$, $4^{\circ} 39^{\prime} 25^{\prime \prime} \mathrm{W}$ ), a tributary of the Alberche river in the Tagus basin located in Central Iberian Peninsula (Figure 1). The catchment has an area of $15.75 \mathrm{~km}^{2}$ and is formed by the confluence of several secondary torrents descending from the Exclusa summit (1,960 $\mathrm{m}$ a.s.1.) to the confluence with the Alberche river (725 m a.s.1.) on the northern slopes of the Sierra del Valle (Gredos mountain range, Spanish Central System). The Arroyo Cabrera is characterized by highly dynamic torrential activity owing to persistent and heavy rainfall events, especially during winter, as well as by a high gradient in the headwaters $(32 \%$ on average), which facilitate the triggering of shallow landslides that mobilize abundant solid material to the channel.

The study site was chosen for two reasons. On one hand, there are data on a low-frequency flash-flood event that took place in this catchment on December 18, 1997 (Bodoque et al. 2006), causing substantial damage to the adjacent vegetation, mainly the Mediterranean conifer $P$. pinaster and riparian species including European alder (Alnus glutinosa (L.) Gaertn.), narrow-leafed ash (Fraxinus angustifolia Vhal.) or poplar (Populus nigra L.). On the other hand, there is a hydrologic monitoring network (2 flow gauges and 6 rain gauges) operational in the catchment since 2004, which allows for the recording of systematic data that can then be compared with results from dendrogeomorphological analyses.

\section{MATERIAL AND METHODS}

\section{Sampling Strategy}

Debris transported by flash-flood events often leads to the abrasion of bark and local cambium damage (Figure 2), resulting in the formation of callus tissue (Schweingruber 1996, 2001). This growth disturbance prevents normal radial growth in the affected zone and induces an anatomical response that can be used as an indicator of trauma related to various geomorphic processes (Bollschweiler et al. 2008a; Stoffel and Hitz 2008; Schneuwly et al. 2009a, b).

Sampling therefore focused on visibly injured trees located on the banks of the torrent and orientated parallel to the flow direction. Scars 


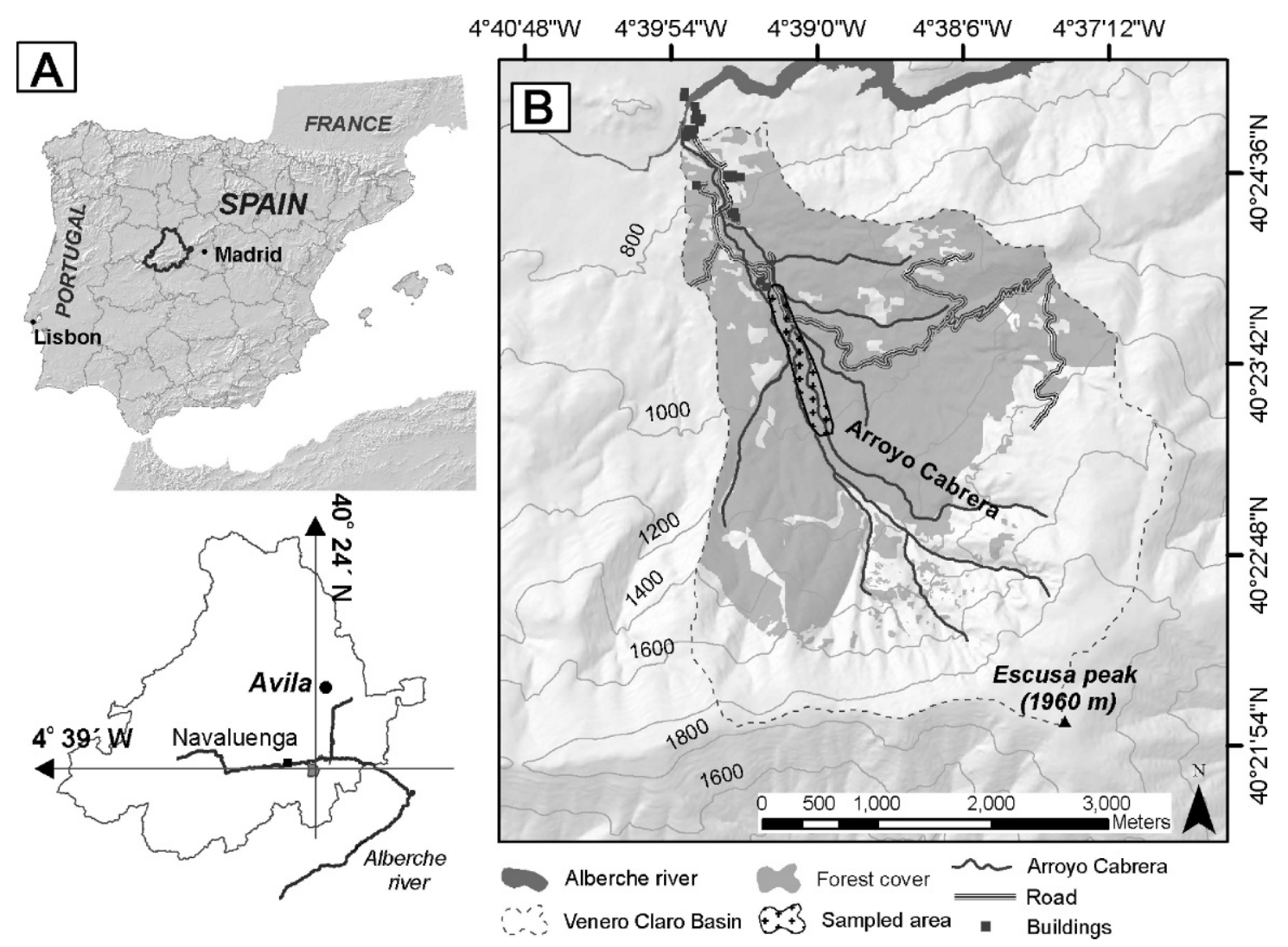

Figure 1. (A) The Arroyo Cabrera is located in the Sierra del Valle (Gredos mountain range) near the village of Navaluenga (Ávila), Central Spain. (B) Schematic map showing the Cabrera basin and the location of the sampled area.

located elsewhere on the stem or with doubtful geometry such as unusually large or elongated scars that could have been generated by the fall of neighboring trees were avoided. Sampling of wounded trees was carried out with a handsaw and wedges were taken from the overgrowing callus. In addition, increment cores were taken from the side facing the wound with Suunto increment borers. Fourteen disturbed $P$. pinaster trees were selected and one wedge and one increment core were collected per tree. We noted the position of each tree with respect to the channel, dendrogeomorphological evidence of flash-flood activity, tree height, tree diameter at breast height $(\mathrm{DBH})$, and tree damage in neighboring trees. In addition, increment cores were taken at breast height (1.3 m; Stoffel and Bollschweiler 2008) from 20 different undisturbed trees next to the torrent system to build a local reference chronology.

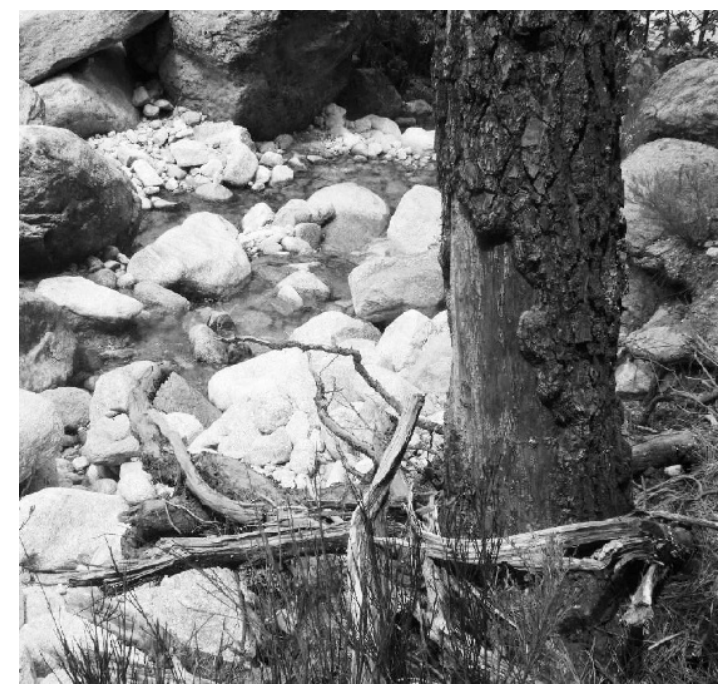

Figure 2. Scar on Maritime pine (Pinus pinaster Ait.) stem caused by the impact of wood and debris transported during a flash flood. 


\section{Macroscopic Analysis}

To identify macroscopic growth disturbances caused by flash-floods events, standard dendrochronological methods were used (Schneuwly and Stoffel 2008). First of all, increment cores were fixed on woody supports and special care was taken to assure that wood fibres were glued vertically on the support (Iseli and Schweingruber 1989) to allow for the analysis of transversal sections. In a next step, cores and wedges were air dried, sanded and polished (up to 400 grit). Thereafter, ring widths were measured with an accuracy of $0.01 \mathrm{~mm}$ for both the disturbed and undisturbed trees using a digital LINTAB positioning table connected to a stereomicroscope and TSAP 3.0 software (Rinntech 2008).

Using the increment data from the undisturbed trees, a local reference chronology was built, representing normal growth conditions at the study site. Ring widths were measured and the series crossdated, indexed and standardized with the TSAP 3.0 software (Rinntech 2008). We used the reference chronology to detect abrupt growth changes in disturbed trees (Shroder 1980; Braam et al. 1987; Strunk 1997; Friedman et al. 2005; Vaganov et al. 2006) by comparing the values of disturbed samples (wedges, cores) with those of the reference chronology for the years preceding and those following the flash-flood event.

In a subsequent step, flash-flood events were dated by locating the year of scar formation in the tree-ring record (Zielonka et al. 2008). In addition, visual procedures were used to identify (i) the intraseasonal position of the wound inside individual tree rings (Schneuwly and Stoffel 2008) and (ii) the presence of callus tissue formed following cambium damage (Larson 1994; Schweingruber 2001; Stoffel and Bollschweiler 2008).

\section{Microscopic Analysis}

Following the tree-ring subdivision proposed by Stoffel et al. (2005) and Stoffel and Hitz (2008), anatomical responses were assessed through the measurement of early earlywood (EE) tracheids, representing the first third of the earlywood. The goal of this microscopic approach was to analyze anatomical changes in $P$. pinaster resulting from flash-flood events, namely changes in (i) lumen area, (ii) cell-wall percentage and cell-wall thickness of EE tracheids, as well as changes in (iii) radial length and tangential width of EE tracheids. In addition, we analyzed differences in the (iv) abundance of resin ducts located in earlywood (EW) and latewood (LW; Stoffel 2008).

Small cubes were cut at a distance of $1.5 \mathrm{~cm}$ from the wound and microslides $(15 \mu \mathrm{m})$ were produced using a sliding microtome equipped with wedge-shaped blades. Samples were prepared as described by Schweingruber (2001), photographed with a digital imaging system at 200 dpi (Leica DFC320). Microscopic images were analyzed at 50× magnification with a precision of $1 \mu \mathrm{m}$ by means of the software WinCell PRO Version 5.6c (Régent Instruments 2008) on an area of about $0.6 \mathrm{~mm}^{2}$.

The analysis of resin ducts, in contrast, was based on a visual observation and direct counting of ducts on the digital images. The area analyzed for resin ducts was defined by the width of the microscopic image $(0.8 \mathrm{~cm})$ and the total length of EW and LW.

In order to determine if anatomical changes were statistically significant, we carried out two non-parametric tests: Friedman and Wilcoxon tests (Sprent and Smeeton 2001) at 95 percent LSD (least significant difference). These analyses were focused on the identification of significant changes of wood-anatomical parameters in two or four years prior to wounding, in the response year, as well as in the two years after the initial response was observed. The Friedman test was used to identify if there are statistically significant differences in the mean ranks across more than two samples considered (i.e. anatomical parameters measurement before wounds, in the response year and after wounds). The Wilcoxon test was used to detect significant differences between measurements values for two related samples (e.g. resin ducts before wounding and resin ducts after wounding).

\section{RESULTS}

\section{Macroscopic Growth Responses and Flash-Flood Dating}

Analysis of the 14 wedges from the scarred $P$. pinaster trees allowed for the dating of three flash- 
flood events in the Arroyo Cabrera torrent. In 10 samples, scars were identified in the 1998 increment ring. The remaining four samples contained two scars in the 1990 and 2005 rings. Analysis of the intra-seasonal position of the 14 wounds and the corresponding callus tissue shows that the three flash-flood events are located in the very first EE tracheid layer, indicating that wounds were inflicted during the dormant season (Figure 3). In the study area, the dormant season extends from October to April, which coincides with the period of major rainfall.

As compared to the reference chronology (Table 1), ring widths of the disturbed trees show a growth decrease by $49.6 \%$ near the injuries and $6.6 \%$ on the opposite side in the 1998 increment ring. Non-parametric statistical tests show that the changes in ring widths are significant for the analyses performed close to the wounds (Friedman: $p=0.000$ and $\left.\chi^{2}=20.64\right)$, but not for the samples selected from the opposite side $(\mathrm{p}=0.604$ and $\left.\chi^{2}=1,848\right)$.

In contrast to the reactions observed after the 1997 event, the reduction of ring widths is much less pronounced for the 1989 and 2004 events. For these events, we observe a decrease in ring width of $24.9 \%$ (1989) and $21.5 \%$ (2004) next to the wound and $18.5 \%$ (1989) and 7.5\% (2004) in the cores taken at the opposite side. Statistical analyses were not performed for these two events because the number of samples $(n=2$ per event $)$ was too low.

\section{Microscopic Analysis and Anatomical Changes Induced by Flash Floods}

The anatomical analysis of wounded $P$. pinaster indicates large decreases in lumen area of EE tracheids as a result of the 1997 flash flood (Table 2 and Figure 4). When compared with the four years preceding wounding, the lumen area of the response year tracheids (i.e. 1998) decreases by more than $50 \%$, whereas in the years following the event, we observe a recovery of lumen area $(32.9 \%)$. Reductions of lumen area are statistically significant with $\mathrm{p}=0.000$ and $\chi^{2}=20$ (Friedman test). At the same time, wounding by the 1997 flash flood resulted in an increase of cell-wall

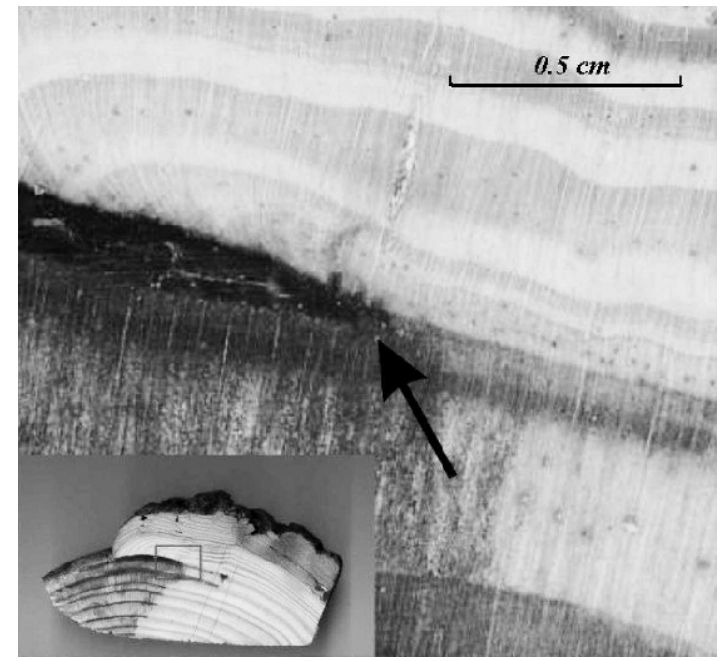

Figure 3. Example of a wedge obtained from a flash-flood scar. The arrow indicates the position of the wound within the treering sequence. The injury is located between the latewood of the previous increment ring and the earlywood of the new ring, suggesting that the impact took place during dormancy.

percentage in EE tracheids by $34.7 \%$ (Figure 5), mainly caused by an increase of cell-wall thickness.

We also observe changes in the radial length and tangential width of EE tracheids following the 1997 flash flood with a decrease of radial lengths by $39 \%$ and tangential widths by $31.6 \%$. Interestingly, the decrease of radial lengths and tangential widths is not only significant (Friedman test: $p=$ 0.000 and 0.012 , respectively) for the response year, but it also seems that recovery in the two years following the initial response is only minimal and not significant (recovery of radial length and tangential width of $19.7 \%$ and $9 \%$, respectively; Wilcoxon test: $p=0.169$ and 0.202 , respectively). Changes of lumen, radial length and tangential width of EE tracheids in relation with the 1997 flash-flood event are illustrated in Figure 6.

The small number of samples $(n=2)$ of the 1989 and 2004 events did not allow the use of statistical tests. Based on the values obtained, we observe, however, similar results for the 1990 and 2005 increment rings as well. The decrease of lumen area amounts to $37.5 \%$ in 2005 following the 2004/05 dormant season event, and 39\% in 1990 as a result of the 1989/90 flash flood. In 
Table 1. Mean $(\mu)$ and standard deviation $(\sigma)$ of increment growth close to the wounds $(1.5 \mathrm{~cm})$ and in cores taken from the opposite side for the response year $(0)$, the two growth rings preceding $(-2,-1)$ and the growth ring succeeding $(+1)$ wounding compared with reference chronology values. The highlighted value indicates the most significant decrease (Wilcoxon test: $\mathrm{p}=0.005$; $\mathrm{Z}=-2.803)$.

\begin{tabular}{|c|c|c|c|}
\hline & \multicolumn{3}{|c|}{ Increment Growth $(1 / 100 \mathrm{~mm})$} \\
\hline & $\begin{array}{l}\text { Ring Widths at } 1.5 \mathrm{~cm} \\
\text { from the Wounds }\end{array}$ & $\begin{array}{l}\text { Ring Widths at } \\
\text { Opposite Side }\end{array}$ & $\begin{array}{l}\text { Reference } \\
\text { Chronology }\end{array}$ \\
\hline \multicolumn{4}{|c|}{ - Response year (1998) } \\
\hline-2 & $\mu=453.3 \sigma=125.9$ & $\mu=377.5 \sigma=112.6$ & 499 \\
\hline-1 & $\mu=484.6 \sigma=111.1$ & $\mu=352.5 \sigma=112.9$ & 500 \\
\hline 0 (Response year) & $\mu=244.1 \sigma=95.7$ & $\mu=365.6 \sigma=195.6$ & 501 \\
\hline 1 & $\mu=289.7 \sigma=102.6$ & $\mu=344.2 \sigma=196.3$ & 500 \\
\hline Friedman test & $\begin{array}{l}\mathrm{n}=10 \\
\chi^{2}=20,64 \\
\mathrm{p}=0.000\end{array}$ & $\begin{array}{l}\mathrm{n}=10 \\
\chi^{2}=1,848 \\
\mathrm{p}=0.604\end{array}$ & - \\
\hline \multicolumn{4}{|c|}{ - Response year (2005) } \\
\hline-2 & $\mu=276.6 \sigma=4.7$ & $\mu=135.5 \sigma=27.5$ & 498 \\
\hline-1 & $\mu=230.0 \sigma=18.8$ & $\mu=159.5 \sigma=48.0$ & 497 \\
\hline 0 (Response year) & $\mu=180.5 \sigma=23.5$ & $\mu=171.5 \sigma=33.9$ & 498 \\
\hline 1 & $\mu=258.3 \sigma=35.3$ & $\mu=198.1 \sigma=19.7$ & 499 \\
\hline \multicolumn{2}{|c|}{ - Response year (1990) } & & \\
\hline-2 & $\mu=290.1 \sigma=28.2 .8$ & $\mu=505.2 \sigma=203.6$ & 506 \\
\hline-1 & $\mu=246.6 \sigma=9.4$ & $\mu=460.0 \sigma=28.2$ & 501 \\
\hline 0 (Response year) & $\mu=185.0 \sigma=21.2$ & $\mu=374.5 \sigma=74.2$ & 502 \\
\hline 1 & $\mu=160.4 \sigma=32.9$ & $\mu=255.5 \sigma=19.5$ & 498 \\
\hline Friedman test & \multicolumn{2}{|c|}{$\mathrm{n}=2$ (not enough observations for statistical tests) } & - \\
\hline
\end{tabular}

addition, the radial length and tangential width experienced decrease as well. As a consequence of the 2004 event, the radial length decreased by $23.6 \%$ and the tangential width by $14.4 \%$, whereas for the 1989 event the decreases were $21.1 \%$ and $18.8 \%$, respectively.

\section{Formation of Resin Ducts as a Response to Flash Floods}

Table 3 summarizes the number of resin ducts (RD) identified in EW and LW after flash flood wounding. In six samples - mainly in those showing the 1997 event - we observe an increase in the median values of RD per surface unit. The median value was $1 \mathrm{RD}$ in EW and 2 RD in LW before wounding, whereas after the impact, we observe 2 and 3 RD, respectively. However, this increase in the number of $\mathrm{RD}$ following flashflood events does not allow conclusion that these changes are significant (Wilcoxon test: $\mathrm{p}=0.087$ and 0.818 , respectively).

\section{DISCUSSION AND CONCLUSIONS}

This study was designed to determine anatomical changes in Pinus pinaster Ait. following wounding through flash floods. We analyzed macroscopic and microscopic changes in $14 P$. pinaster samples that were scarred by debris transported during flash floods. Based on the analysis of the scars, it was possible to identify three flash-flood events over the last 20 years, namely in 1989, 1997 and 2004.

Comparable techniques have been applied in the past to date floods based on anatomical changes in coniferous (Yamamoto and Kozlowski 1987; Yamamoto et al. 1987; Yamamoto 1992) and broadleaved species (Yanosky 1984; Astrade and Bégin 1997; Kozlowski 1997; St George et al. 2002). However, results obtained in these previous studies cannot be easily compared with those of the present study, as anatomical responses of trees to persistent floods (i.e. several days to several weeks) result from an interruption of growth 
Table 2. Mean $(\mu)$ and standard deviation $(\sigma)$ of changes in radial length, tangential width and lumen area of early earlywood (EE) tracheids at $1.5 \mathrm{~cm}$ from the wounds. Statistical tests (Friedman test) indicate significant differences for the three parameters and for the response year, the four growth rings preceding and the two succeeding the event.

\begin{tabular}{|c|c|c|c|c|}
\hline & $\begin{array}{l}4 \text { Years Before } \\
\text { Wounding }\end{array}$ & $\begin{array}{l}\text { Response } \\
\text { Years }\end{array}$ & $\begin{array}{l}2 \text { Years Following } \\
\text { Wounding }\end{array}$ & $\begin{array}{l}\text { Friedman } \\
\text { Test }\end{array}$ \\
\hline \multicolumn{5}{|c|}{ Lumen area $\left(\mu \mathrm{m}^{2}\right)$} \\
\hline 1997 event & $\begin{array}{l}\mu=207.02 \\
\sigma=50.62\end{array}$ & $\begin{array}{l}\mu=100.23 \\
\sigma=39.93\end{array}$ & $\begin{array}{l}\mu=133.21 \\
\sigma=40.20\end{array}$ & $\begin{array}{l}\chi^{2}=20 \\
p=0.000\end{array}$ \\
\hline 2004 event & $\begin{array}{l}\mu=169.90 \\
\sigma=14.2\end{array}$ & $\begin{array}{l}\mu=102.96 \\
\sigma=6.3\end{array}$ & $\begin{array}{l}\mu=174.75 \\
\sigma=28.9\end{array}$ & - \\
\hline 1989 event & $\begin{array}{l}\mu=166.90 \\
\sigma=76.3\end{array}$ & $\begin{array}{l}\mu=104.30 \\
\sigma=47.6\end{array}$ & $\begin{array}{l}\mu=123.56 \\
\sigma=30.26\end{array}$ & - \\
\hline \multicolumn{5}{|c|}{ Radial length $(\mu \mathrm{m})$} \\
\hline 1997 event & $\begin{array}{l}\mu=13.68 \\
\sigma=2.58\end{array}$ & $\begin{array}{l}\mu=8.31 \\
\sigma=2.82\end{array}$ & $\begin{array}{l}\mu=9.95 \\
\sigma=3.31\end{array}$ & $\begin{array}{l}\chi^{2}=16.8 \\
p=0.000\end{array}$ \\
\hline 2004 event & $\begin{array}{l}\mu=11.85 \\
\sigma=0.44\end{array}$ & $\begin{array}{l}\mu=9.05 \\
\sigma=1.13\end{array}$ & $\begin{array}{l}\mu=10.11 \\
\sigma=1.13\end{array}$ & - \\
\hline 1989 event & $\begin{array}{l}\mu=10.20 \\
\sigma=1.1\end{array}$ & $\begin{array}{l}\mu=8.05 \\
\sigma=1.06\end{array}$ & $\begin{array}{l}\mu=8,65 \\
\sigma=0.26\end{array}$ & - \\
\hline \multicolumn{5}{|c|}{ Tangential width $(\mu \mathrm{m})$} \\
\hline 1997 event & $\begin{array}{l}\mu=11.45 \\
\sigma=1.83\end{array}$ & $\begin{array}{l}\mu=7.88 \\
\sigma=3.48\end{array}$ & $\begin{array}{l}\mu=8.59 \\
\sigma=3.41\end{array}$ & $\begin{array}{l}\chi^{2}=8.769 \\
p=0.012\end{array}$ \\
\hline 2004 event & $\begin{array}{l}\mu=11.2 \\
\sigma=0.41\end{array}$ & $\begin{array}{l}\mu=9.90 \\
\sigma=0.42\end{array}$ & $\begin{array}{l}\mu=10.05 \\
\sigma=2.05\end{array}$ & - \\
\hline 1989 event & $\begin{array}{l}\mu=9.35 \\
\sigma=1.62\end{array}$ & $\begin{array}{l}\mu=8.00 \\
\sigma=1.27\end{array}$ & $\begin{array}{l}\mu=8.35 \\
\sigma=0.91\end{array}$ & - \\
\hline
\end{tabular}

hormone transport (i.e. lack of soil aeration; St. George et al. 2002; Kozlowski 1997). However, in our case, trees are affected by flash-flood activity in a high gradient stream. This process is shortlasting (i.e. a few hours), has high energies and large sediment transport rates, thus favoring the formation of injuries.

All flash floods reconstructed in this study occurred during the dormant season (i.e. 1989/90, $1997 / 98$ and 2004/05), when rainfall activity is

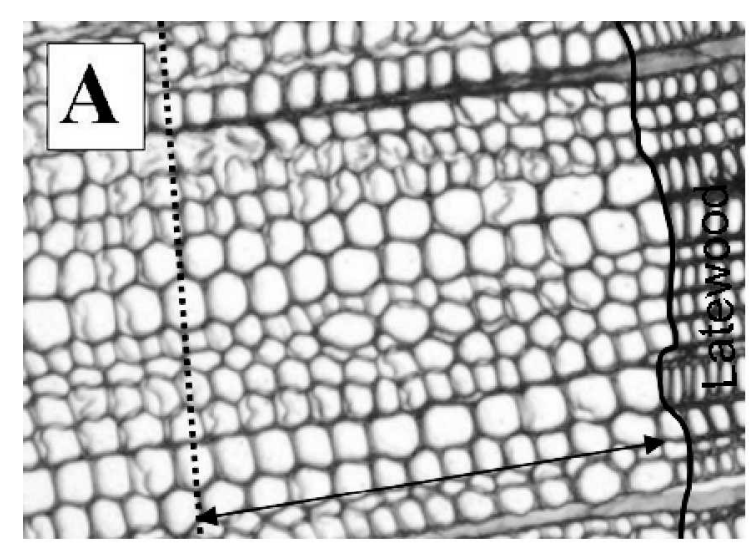

$E E=1 / 3 E W$

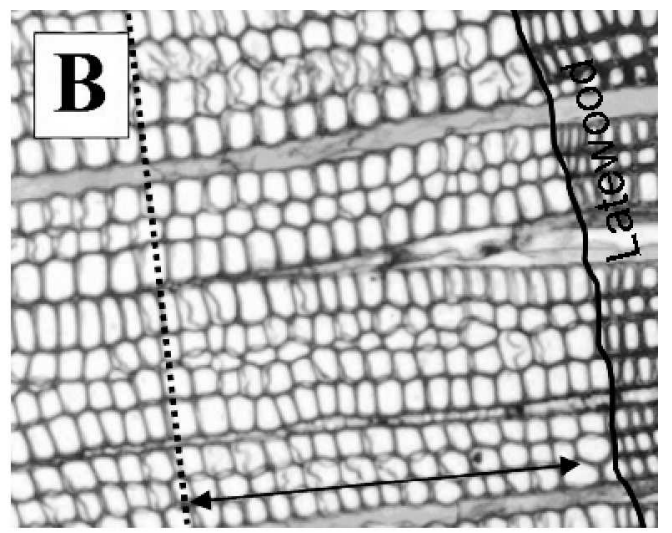

$E E=1 / 3 \mathrm{EW}$

Figure 4. Early earlywood (EE) tracheids of Pinus pinaster: (A) EE tracheids in the increment ring preceding wounding; (B) EE tracheids formed in the response year with the characteristic decrease in the tangential width, radial length and lumen size. 


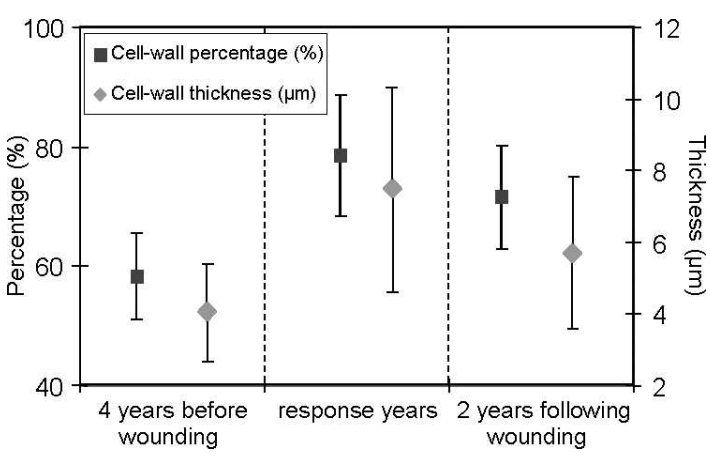

Figure 5. Changes observed in cell-wall percentage and cell-wall thickness of EE tracheids before and after wounding in $P$. pinaster Ait.

highest at the study site (Díez 2001). Based on hydrometeorological records available for the wider study region, it is also possible to characterize the three events. The low-frequency event that took place on December 18, 1997, was the result of heavy rainfalls of almost $153 \mathrm{~mm}$ day $^{-1}$ falling onto a saturated soil, resulting in a peak flash-flood discharge of about $593 \mathrm{~m}^{3} / \mathrm{s}$ and high sediment load (Bodoque et al. 2006). The hydrologic monitoring network installed in 2004 in the catchment registered a small event in October 18-20, 2004, when a peak discharge of $22.7 \mathrm{~m}^{3} / \mathrm{s}$ was registered following rainfall of $127.4 \mathrm{~mm} \mathrm{day}^{-1}$ and a peak intensity of $114 \mathrm{~mm} \mathrm{~h}^{-1}$ (Bodoque et al. 2006). The absolute dating of the oldest event was possible via the analysis of flow-gauge data from the receiving Alberche River, located $6 \mathrm{~km}$ downstream of the study site. The Alberche River, with a catchment area of $698 \mathrm{~km}^{2}$ above the flow gage considered in this study, recorded a peak discharge of $552.4 \mathrm{~m}^{3} / \mathrm{s}$ between December 14-18, 1989 (Díez 2001).
From our data and in contrast to the increase observed in the reference chronology, the growth decrease in the tree-ring segments neighbouring the wounds was much more important after the 1997 flash flood (49.6\%) than after the 1989 (24.9\%) and 2004 events (21.5\%). On the cores taken on the opposite side of the wound, however, we observe a growth decrease by almost $19 \%$ and $8 \%$ following the 1989 and 2004 events, but a reduction of only $6.6 \%$ after the 1997 flash flood. As some of the trees were not only injured but also tilted by the 1997 flash flood, it is possible that the production of compression wood would have almost compensated the growth reduction.

Nevertheless, it seems that the magnitude of events and forces involved could have an influence on the intensity of the anatomical reaction. The peak discharge of the 1997 event was more than an order of magnitude larger than the flash flood that occurred in 2004. A higher peak discharge will increase the amount of detritus being transported in the larger size classes. As a consequence, greater wounds and stronger anatomical reactions are observed after the 1997 event as compared to the 2004 event.

The paper also illustrates that anatomical changes in $P$. pinaster could be used for the identification of flash-flood events. These changes are basically related to (i) a decrease in lumen area, (ii) an increase of cell-wall thickness, and (i) a decrease of the radial length and tangential width of EE tracheids. On average, lumen area was reduced by almost $50 \%$ as a consequence of wounding by flash floods. This response is consistent with results published by Fahn and Zamski (1970), who
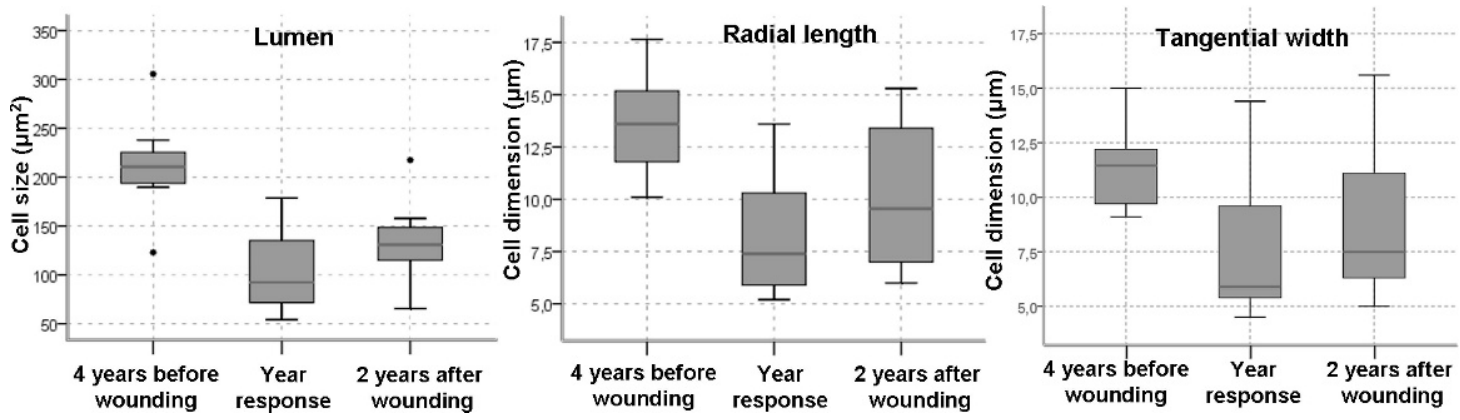

Figure 6. Box plots showing changes in lumen area, radial length and tangential width of EE tracheids as a result of wounding by the 1997 flash-flood event. EE tracheids in the response year are compared with those formed 4 years before and 2 years after wounding. 
Table 3. Number of resin ducts observed in the earlywood (EW) and latewood (LW) in the response year as compared to the median of the four previous years.

\begin{tabular}{|c|c|c|c|c|}
\hline \multirow[b]{3}{*}{ Response Year } & \multicolumn{2}{|c|}{ Resin Ducts EW } & \multicolumn{2}{|c|}{ Resin Ducts LW } \\
\hline & Before & After & Before & After \\
\hline & Wounding & Wounding & Wounding & Wounding \\
\hline \multicolumn{5}{|l|}{1998} \\
\hline Mean & 1.15 & 2.5 & 2 & 2.9 \\
\hline SD & 1.38 & 2.01 & 1.08 & 2.42 \\
\hline Median & 1 & 2 & 2 & 3 \\
\hline Wilcoxon test & \multicolumn{2}{|c|}{$\mathrm{p}=0.087$} & \multicolumn{2}{|c|}{$\mathrm{p}=0.818$} \\
\hline \multicolumn{5}{|l|}{1990} \\
\hline Mean & 1.5 & 1 & 3 & 3 \\
\hline SD & 1.41 & 1.41 & 1.41 & 1.41 \\
\hline \multicolumn{5}{|l|}{2005} \\
\hline Mean & 0 & 2.5 & 1.25 & 1 \\
\hline SD & 0 & 2.12 & 0.35 & 0 \\
\hline
\end{tabular}

reported the existence of smaller "traumatic tracheids" in Pinus halepensis Mill. following wounding. Comparable changes in tracheid dimensions were also described for juvenile Larix decidua Mill. trees injured by rockfall and snow avalanches (Stoffel and Hitz 2008). In contrast, Yamamoto et al. (1987) and Yamamoto and Kozlowski (1987) did not observe changes in tracheid size in $P$. halepensis and Pinus densiflora Sieb. et Zucc. affected by persistent floods.

Resin ducts are generally considered an excellent growth disturbance-induced feature for the dating of geomorphological processes, provided that they appear in compact and continuous, tangentially oriented rows (Lafortune et al. 1997; Bollschweiler et al. 2008b; Stoffel 2008). However, Pinus sp. do not normally form traumatic ducts and individual canals appear dispersed and only rarely in tangential bands (Bannan 1936). In particular, $P$. pinaster has a well developed vertical system of resin ducts in xylem tissues located close to the latewood transition (Castellarnau 1883; Schweingruber 1990). Although our data show a slight increase in the median values of resin ducts in six samples, it was not possible to identify clear signatures that would have allowed for the use of resin ducts as an indicator of flash-flood events. This finding is in agreement with Stoffel (2008), who dissuades the use of resin ducts for the dating of geomorphic processes in Pinus sp.
In conclusion, the preliminary analysis of Pinus pinaster Ait. has allowed identification of different anatomical signatures following wounding by flash-flood events, namely (i) a significant decrease in ring widths close to the cambial damages, (ii) a significant decrease in lumen area of EE tracheids, (iii) an increase in cell-wall percentage caused by an increase in cell-wall thickness in EE tracheids, and (iv) a significant reduction of radial lengths of EE tracheids. These findings will greatly help future dendrogeomorphological studies on flash-flood events based on $P$. pinaster to use non-destructive sampling techniques and to analyze a much larger number of trees for the assessment of hazards and risks in ungauged basins in Mediterranean ecosystems.

\section{ACKNOWLEDGMENTS}

The authors acknowledge the valuable comments from the anonymous reviewers. The kind collaboration of the Environment Department of Ávila (Castilla-Leon), especially forester J. L. Galán, was essential for this study. This paper was funded in part by CICYT, the DendroAvenidas project (number CGL2007-62063 of the Spanish Ministry of Science and Innovation) and by the Geological Survey of Spain (Instituto Geológico y Minero de España-IGME).

\section{REFERENCES CITED}

Alestalo, J., 1971. Dendrochronological interpretation of geomorphic processes. Fennia 105:1-140.

Astrade, L., and Y. Bégin, 1997. Tree-ring response of Populus tremula $L$. and Quercus robur $L$. to recent spring floods of the Sâone River, France. Ecoscience 4:232-239.

Bannan, M. W., 1936. Vertical resin ducts in the secondary wood of the Abietineae. New Phytologist 35:11-46.

Bodoque, J. M., A. Díez, J. De Pedraza, J. F. Martín, and J. F. Olivera, 2006. Estimación de la carga sólida en avenidas de derrubios mediante modelos geomecánicos, hidrológicos e hidráulicos combinados: Venero Claro (Ávila). In Geomorfología y Territorio, edited by A. Pérez, and J. López, pp. 483-495. Universidad de Santiago de Compostela.

Bollschweiler, M., M. Stoffel, and D. M. Schneuwly, 2008a. Dynamics in debris-flow activity on a forested cone - a case study using different dendroecological approaches. Catena 72:67-78.

Bollschweiler, M., M. Stoffel, D. M. Schneuwly, and K. Bourqui, 2008b. Traumatic resin ducts in Larix decidua stems impacted by debris flows. Tree Physiology 28:255-263. 
Braam, R. R., E. E. J. Weiss, and A. Burrough, 1987. Dendrogeomorphological analysis of mass movement: A technical note on the research methods. Catena 14:585589.

Castellarnau y Lleopart, J. M., 1883. Estudio micrográfico del sistema leñoso de las coníferas y en general del Género Pinus. Anales de la Sociedad Española de Historia Natural. Vol. 12: Cuaderno $\mathrm{n}^{\circ} 1$ and Cuaderno $\mathrm{n}^{\circ} 2$.

Díez, A., 2001. Geomorfología e Hidrología fluvial del río Alberche. Modelos y SIG para la gestión de riberas. $\mathrm{PhD}$ thesis. Universidad Complutense de Madrid, Madrid. http:// www.ucm.es/BUCM/tesis/geo/ucm-t25361.pdf.

Fahn, A., and E. Zamski, 1970. The influence of pressure, wind, wounding and growth substances on the rate of resin duct formation in Pinus halepensis wood. Israel Journal of Botany 19:429-446.

Friedman, J. M., K. R. Vincent, and P. B. Shafroth, 2005. Dating floodplain sediment using tree-ring response to burial. Earth Surface Processes and Landforms 30:1077-1091.

Gottesfeld, A. S., 1996. British Columbia flood scars: Maximum flood-stage indicator. Geomorphology 14:319-325.

Harrison, S. S., and J. R. Reid, 1967. A flood-frequency graph based on tree-scar data. Proceedings of the National Academy of Sciences 21:23-33.

Hupp, C. R., 1988. Plant ecological aspect of flood geomorphology and paleoflood history. In Flood Geomorphology, edited by V. R. Baker, R. C. Kochel, and P. C. Patton, pp. 335-356. John Wiley and Sons, New York.

Iseli, M., and F. H. Schweingruber, 1989. Sichtbarmachen von Jahrringen für dendrochronologische Untersuchungen. Dendrochronologia 4:145-157.

Kozlowski, T. T., 1997. Responses of woody plants to flooding and salinity. Tree Physiology Monograph 1:1-29.

Lafortune, M., L. Filion, and B. Hétu, 1997. Dynamique d'un front forestier sur un talus d'éboulis actif en climat tempéré froid (Gaspésie, Québec). Géographie Physique et Quaternaire 51:1-15.

Larson, P. R., 1994. The Vascular Cambium. Development and Structure. Springer, Berlin.

McCord, V. A., 1996. Fluvial process dendrogeomorphology: Reconstruction of flood events from the southwestern United States using flood-scarred trees. In Tree Rings, Environment and Humanity, edited by J. S. Dean, D. M. Meko, and T. W. Swetnam, pp. 689-699. Radiocarbon, Tucson.

Régents Instruments, 2008. WinDendro for tree-ring, stem, wood density analysis and measurement, http://www. regentinstruments.com/.

Rinntech, 2008. LINTAB. Precision ring by ring. http://www. rinntech.com/Products/Lintab.htm.

Roca, M., J. P. Martín-Vide, and P. J. M. Moreta, 2009. Modelling a torrential event in a river confluence. Journal of Hydrology 364:207-215.

Scheuren, J-M., O. le Polain de Waroux, R. Below, and D. Guha-Sapir, 2008. Annual Disaster Statistical Review: The Numbers and Trends 2007. Centre for Research on the Epidemiology of Disasters (CRED), Catholic University of Louvain (UCL), Brussels. http://www.emdat.be/.
Schneuwly, D. M., and M. Stoffel, 2008. Spatial analysis of rockfall activity, bounce heights and geomorphic changes over the last 50 years-A case study using dendrogeomorphology. Geomorphology 102(3-4):522-531.

Schneuwly, D. M., M. Stoffel, and M. Bollschweiler, 2009a. Formation and spread of callus tissue and tangential rows of resin ducts in Larix decidua and Picea abies following rockfall impacts. Tree Physiology 29:281-289.

Schneuwly, D. M., M. Stoffel, L. K. A. Dorren, and F. Berger, 2009b. Three-dimensional analysis of the anatomical growth response of European conifers to mechanical disturbance. Tree Physiology 29:1247-1257.

Schweingruber, F. H., 2001. Dendroökologische Holzanatomie. Paul Haupt, Bern, Stuttgart, Wien.

Schweingruber, F. H., 1996. Tree Rings and Environment, Dendroecology. Paul Haupt, Bern, Stuttgart, Wien.

Schweingruber, F. H., D. Eckstein, F. Serre-Bachet, and O. U. Bräker, 1990. Identification, presentation and interpretation of event years and pointer years in dendrochronology. Dendrochronologia 8:9-39.

Shroder, J. F., 1980. Dendrogeomorphology: Review and new techniques of tree-ring dating. Progress in Physical Geography 4:161-188.

Sprent, P., and N. C. Smeeton, 2001. Applied Nonparamentric Statistical Methods. Chapman \& Hall/CRC, Boca Raton, London, New York, Washington, D.C.

St. George, S., E. Nielsen, F. Conciatori, and J. Tardif, 2002. Trends in Quercus macrocarpa vessel areas and their implications for tree-ring paleoflood studies. Tree-Ring Research 58(1/2):3-10.

Stoffel, M., 2008. Dating past geomorphic processes with tangential rows of traumatic resin ducts. Dendrochronologia 26:53-60.

Stoffel, M., and M. Bollschweiler, 2008. Tree-ring analysis in natural hazards research-an overview. Natural Hazards and Earth System Sciences 8:187-202.

Stoffel, M., and O. M. Hitz, 2008. Snow avalanche and rockfall impacts leave different anatomical signatures in tree rings of Larix decidua. Tree Physiology 28(11):1713-1720.

Stoffel, M., D. Conus, M. A. Grichting, I. Lièvre, and G. Maitre, 2008. Unraveling the patterns of late Holocene debris-flow activity on a cone in the Swiss Alps: Chronology, environment and implications for the future. Global and Planetary Change 60(3-4):222-234.

Stoffel, M., I. Lièvre, M. Monbaron, and S. Perret, 2005. Seasonal timing of rockfall activity on a forested slope at Täschgufer (Valais, Swiss Alps) - A dendrochronological approach. Zeitschrift für Geomorphologie 49(1):89-106.

Strunk, H., 1997. Dating of geomorphological processes using dendrogeomorphological methods. Catena 31:137-151.

Tardif, J., and Y. Bergeron, 1997. Ice-flood history reconstructed with tree-rings from the southern boreal forest limit, western Québec. Holocene 7:291-300.

Vaganov, E. A., M. K. Hughes, and A. V. Shashkin, 2006. Growth Dynamics of Conifer Tree Rings. Images of Past and Future Environments. Springer, Berlin, Heidelberg, New York. 
Wimmer, R., 2002. Wood anatomical features in tree-rings as indicators of environmental change. Dendrochronologia 20: 21-36.

Yamamoto, F., 1992. Effects of depth of flooding on growth and anatomy of stems and knee roots of Taxodium distichum. IAWA Bulletin 13:93-104.

Yamamoto, F., and T. T. Kozlowski, 1987. Effect of flooding, titling of stem, and ethrel application on growth, stem anatomy, and ethylene production of Pinus densiflora seedlings. Journal of Experimental Botany 38:293-310.

Yamamoto, F., T. T. Kozlowski, and K. E. Wolter, 1987. Effect of flooding on growth, stem anatomy, and ethylene production of Pinus halepensis seedlings. Canadian Journal of Forest Research 17:69-79.
Yanosky, T. M., 1984. Documentation of high summer flows on the Potomac River from the wood anatomy of ash trees. Water Resource Bulletin 20:241-250.

Yanosky, T. M., and R. D. Jarrett, 2002. Dendrochronologic evidence for the frequency and magnitude of paleofloods. ancient floods, modern hazards: Principles and application of paleoflood hydrology. Water Science and Application 5: 77-89.

Zielonka, T., J. Holeksa, and S. Ciapala, 2008. A reconstruction of flood events using scarred tree in the Tatra Mountains, Poland. Dendrochronologia. doi:10.1016/j.dendro.2.

Received 3 April 2009; accepted 22 January 2010. 